The Canadian Journal of Higher Education, Vol. XXIV-2, 1994

La revue canadienne d'enseignement supérieur, Vol. XXIV-2, 1994

\title{
Reform in Canadian Universities
}

\author{
J.M. SMALL*
}

\begin{abstract}
This article reports a survey of academic vice-presidents and deans of Canadian universities which was undertaken in 1991. The focal topic was reform (defined as significant change), and perceptions of reform occurring over the past three years were derived by means of a questionnaire. Many changes were reported, giving the impression of highly responsive institutions, but these reforms were seen to be modest rather than bold in nature and reactive rather than pro-active. The major environmental influence impelling change was the level of funding. The reforms perceived to be most frequent and significant were mandate changes arising from strategic planning, responses to funding constraints, curriculum expansion, coping with increased student numbers, changes in administrative structure especially at the vice-presidency, and more democratic decision-making.

Respondents were generally supportive of the goals which were perceived to lie behind the reforms but were not convinced that significant progress towards goals was actually being achieved. A comparison with reform in other parts of the world revealed that Canadian universities follow the decentralized ad hoc pattern found in federal nations, but there is reason to hope that strategic planning will produce a clearer sense of direction than has been typical elsewhere.

The report concludes that the claim that universities are not responsive to changing societal needs is unwarranted, but that more significant lasting reforms are needed.
\end{abstract}

* University of Alberta 


\section{Résumé}

Cet article rapporte les résultats d'une enquête effectuée en 1991 auprès de vice-recteurs et de doyens d'universités canadiennes. Le but de cette enquête était d'évaluer les changements importants s'étant opérés dans les établissements durant les trois dernières années ainsi que les perceptions qu'en avaient les répondant(e)s à l'enquête.

Les personnes interrogées ont fait part d'un grand nombre de cas donnant l'impression que les établissements s'adaptaient résolument au changement. Mais après analyse, il appert que les changements identifiés sont plus modestes que décisifs et de nature davantage réactive que pro-active. L'élément déterminant ayant déclenché la plupart des actions entreprises se rapportait au financement des établissements. Les changements les plus fréquents et importants observés touchaient les mandats découlant de la planification stratégique, des coupures budgétaires, des croissances de clientèle étudiantes, des changements dans les structures administratives, particulièrement au niveau de la vice-présidence, ou des processus plus démocratiques de prise de décision.

Les personnes interrogées appuyaient, de façon générale, les objectifs poursuivis mais ne croyaient pas que des changements en profondeur s'étaient opérés par rapport à ces objectifs. Une comparaison avec d'autres systèmes d'éducation ailleurs dans le monde révèle que les universités canadiennes présentent des modes de gestion décentralisée et ad hoc semblables à ceux observés ailleurs dans les nations constituées en fédération, mais qu'il y a lieu d'espérer que la planification stratégique amènera les établissements à mieux clarifier leurs orientations.

Cette étude conclut que les universités tentent réellement de répondre aux attentes de leur milieux, mais que des changements plus substantiels sont nécessaires.

\section{Introduction}

In 1991, a survey was undertaken of academic vice-presidents and deans of education, arts, and science in Canadian universities. The survey on the topic of reform was designed to explore the extent to which Canadian universities are responding to forces of change. In a report prepared for the Commission of Inquiry on Canadian University Education (the Smith Commission), the views of some government officials were summed up as follows: 
The consensus was that universities have not kept up with changing societal demands, have not remained relevant and are either unwilling or unable to change. The words most frequently used to describe them were 'remote,' 'isolated,' 'elitist,' 'arrogant,' and 'naive.' (Public Affairs Management Inc., 1991, Executive Summary)

Are Canadian universities as unresponsive as some appear to believe? Or is there evidence that universities are keeping up with changing expectations? The study which is reported here was designed to explore the extent to which Canadian universities are experiencing change, and to learn more about the phenomenon of change. Miller (1990), in considering the challenges facing postsecondary administrators in the 1990s, argues that administrators will need to be well versed in the change process and change models, and especially in understanding "how ideas and innovations can be more effectively developed, implemented, and evaluated" (p. 211). This study was intended to cast light on the current state of the art of change in Canadian universities.

\section{The Concepts of Change and Reform}

No matter how steeped in tradition they may be, colleges and universities have changed to accommodate social developments and the forces of history. Stadtman (1980) reached this conclusion from his review of Hodgkinson's (1971) landmark study of how colleges in the United States responded to the challenges of the 1960s and from his own study of the 1970s. In the last half century, higher education has undergone a remarkable transformation. In the case of the United States of America, Millard (1991, p. xi) notes that a relatively small, elitist, and largely private system has become a system of universal access with more than twelve and a half million students. Likewise, Canadian higher education has evolved from a loose national system with ad hoc funding in 1959 into a complex web of provincially coordinated institutions (Sheffield, 1978, pp. 6-33). Similar major reforms have occurred in all corners of the world: for example in Britain (Silver, 1990), Australia (Ronayne, 1988), and in Europe (Cerych \& Sabatier, 1986 and van Vught, 1989).

The imperative of change continues to this day. According to Meek, Goedegebuure, Kivenen, and Rinne (1991):

Many national systems of higher education are experiencing profound change. Nearly everywhere, governments are asking their respective higher education systems to participate more effectively and efficiently in producing a better educated, culturally enriched, and more economically secure society. (p. 451) 
The authors note, however, that since the phenomenon of change differs from country to country, comparative studies are needed to answer two fundamental questions: what is the regulatory relationship between government and higher institutions? And, what has been the institutional response to government policy initiatives, and to what effect? (pp.457, 458).

While the scope of reform can be broad and system-wide, as in the aforementioned cases; it can also be narrow and focused. A 1973 inventory sponsored by the Carnegie Commission reported "hundreds of new practices under such headings as new innovative institutions, innovative institutions within institutions, and such procedural innovations as new degrees and changes in grading" (Burton R. Clark in Cerych \& Sabatier, 1986, p. 262). Similarly, Mathurin (1991) in a telephone survey of instructional innovation in Canadian universities reported a plethora of new developments in programs and curricula across the country.

Although there is an extensive literature on reform, there is no consistency in the terms to describe it, including innovation and planned change. Reform usually implies some significant change of policy or direction aimed at correcting a perceived deficiency or misalignment. In their study of reform in higher education in Europe, Cerych \& Sabatier (1986) defined reform as " new policy of higher education" (p. 7). In the same book, Clark Kerr states that he has come to doubt the use of the word reform. Reform means new and improved but for most innovations that claim to be reforms, it is seldom established that improvement has occurred (p. xvi). Kerr also distinguishes between reform and response- "Reform is something someone wants to do in relation to a set of values; response is something someone must do in reaction to the situation" (p. $\mathrm{xvi}$ ). For purposes of the survey which is reported here, reform was defined as significant change, the respondents being left to decide what in their minds was significant. The lack of definitional precision is revealed in this study since many of the examples of reform cited appear to be more in the order of responses (in Kerr's terms).

\section{The Survey}

The survey was structured around the following major questions: i) What are the principal areas of reform in Canadian universities over the past three years? ii) Who are the principal agents of change? iii) What are the perceived goals of reform?

A systems model (Small, Konrad, Hassen, and Pickard, 1976, p. 9) was used to develop a comprehensive listing of 17 possible areas of reform. 
Dennison and Levin's (1988) inventory of community college goals was used as the starting point for creating a list of potential goals of reform. In addition, the questionnaire contained items to identify the influence of various agents in bringing about change, as well as several open-ended questions on reform.

The questionnaire was mailed to vice-presidents (academic) in all 67 Canadian universities, and to a sample of deans of faculties of education, arts, and science. The choice of vice-presidents academic and deans was made to ensure that academic aspects of reform were addressed. The potential for bias is acknowledged, but, given that a sampling decision had to be made, the choice of sample is one which best reflected the focus of interest of the study. Education, arts, and science were the faculties chosen because they tend to be the largest faculties and are to be found in most universities. In this way, a consistency in the sampling of faculties across Canada was assured, although again it resulted in a potential bias in the perspectives reported. An attempt to counteract this bias was made by phrasing questions to embrace the entire university rather than focusing on the home faculty of the respondent. While it is acknowledged that the sampling technique was shaped more by faith than scientific rigor, it was justified on the grounds that the the senior academic officers have a valid view to offer. Furthermore, the product is presented as a snapshot of perceptions across the university sector and not as a comprehensive and objective analysis of the complete phenomenon of reform as it is unfolding in these institutions. Had other respondents been selected, such as presidents or department heads or deans of other faculties, the perceptions would have been different. The purposive sample of deans was drawn as follows: in those universities with faculties of education, a one third sample was randomly selected. Thereafter, the remaining universities were alternately designated for selection of arts or science. By this process, 67 vice-presidents and 66 deans (distributed equally between education, arts, and science) were selected, giving a total sample of 133.

Responses were designed to be anonymous unless the respondents chose to supply their names. An explanatory letter and a subsequent reminder were sent to all respondents. Fifty-seven usable responses were obtained (43\%). Vicepresidents responded at a higher rate than deans-54\% compared to $32 \%$. Since the type of university and province were known, it was deduced that responses were received from at least 36 universities and from all provinces with the exception of Prince Edward Island.

Because of the limitations in sampling, no attempt was made at inferential analysis, such as exploring differences in perceptions held by vice-presidents 
and deans, or between provinces, or different types of university. The questionnaire did ask for a description of the university in terms of size (small - under 5,000 students; medium - 5,000 to 15,000; large - over 15,000); type (liberal arts; specialized; comprehensive); and major languages of instruction (English; French; Bilingual). This information was used simply to enhance the description of the reforms and not as a basis of analysis.

\section{Principal Reforms}

All 17 areas of university operations were identified as having been subject to reform, and all respondents checked several areas as having been targets of change in their institutions, indicating that reform is widespread within Canadian universities. Two respondents claimed to have experienced reforms in 16 areas.

Table 1 lists the areas of change in the order of frequency of checking. The six most frequently reported were also identified by respondents as the six most significant in terms of impact on their institutions. Therefore, comments associated with these items are presented below.

\section{Mandate and/or Goals}

The greatest number of comments dealt with the reformulation of mandates and goals through strategic planning, a process which seems to be widespread. The resulting directions are quite diverse. In several cases, the strategic plan produced a clearer emphasis on liberal arts education and, in one small university, a greater emphasis on rural and northern education. Another institution obtained a new charter which changed it from a private religious institution to a public university. A large comprehensive university placed more emphasis on research and graduate studies. In several universities, changed mandates resulted in the creation of new certificate and degree programs and in two others to a renewed commitment to French as a language of instruction. There was no evidence of significant contraction of mandates.

\section{Funding}

The most common comment referred to government grants not keeping up with inflation. This situation has forced cutbacks in numerous areas and caused difficulties in maintenance of programs and capital facilities. One respondent noted that there was a shrinking endowment at a time of great reliance on it. A large university has an accumulated deficit of $\$ 100 \mathrm{M}$, resulting in debt servicing of $\$ 8 \mathrm{M}$ annually. Changes resulting from the financial squeeze include rapidly 
Table 1

Respondents Reporting Change in Selected Areas

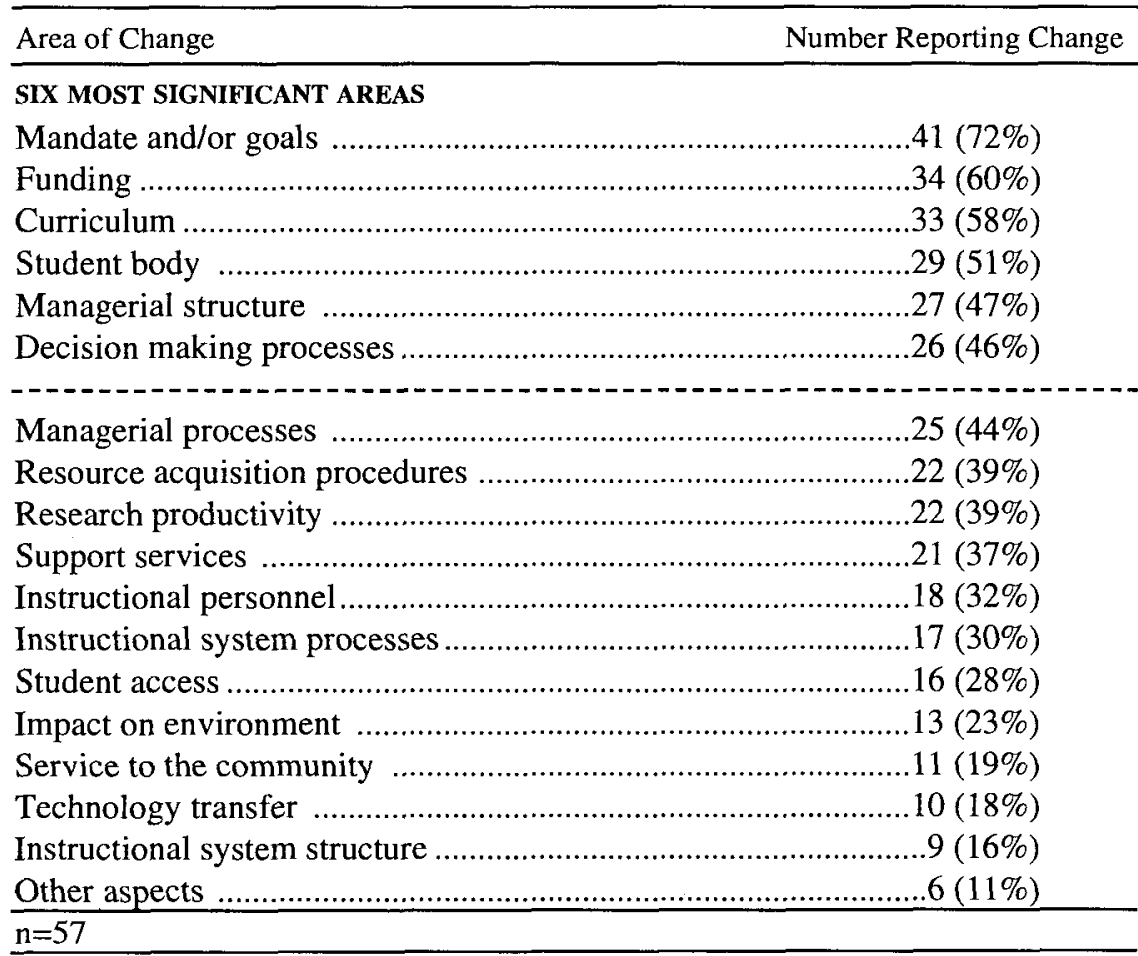

increasing tuition fees; novel fund-raising ventures; new internal cutback procedures; and administrative restructuring. Government funding was not expected to improve in the foreseeable future. As well as the general trend towards declining levels of funding, inconsistency of funding appears to have affected institutional planning in some universities which have experienced variable degrees of increases and reductions over the years.

Positive changes were seldom mentioned. Respondents from British Columbia referred to several innovations: centres of excellence funding provisions, a program of government grants to match private sector donations, expanded capital grants, and "access for all" program funding to provide added places at full cost recovery. One Ontario respondent commented on enrollment "target corridor" funding which was introduced in 1987-88 and revised in 1990-91 when special funding for accessibility was made permanent. 


\section{Curriculum}

Several respondents noted that their universities had introduced internal and external reviews in keeping with a new policy of curriculum evaluation and accountability. Academic units are examining their curricula, programs, courses, clientele, and forms of service to the community. The specific nature of curriculum change follows the changing mandates of some universities. One small liberal university has strengthened its BA degree by the introduction of an advanced major in all departments. Programs have been expanded in a wide range of subjects including child studies, mathematics and statistics, biology and anthropology, chemistry, physical education, computing, third world studies, foreign languages (including Arabic and Japanese), humanities, women's studies, English as a second language, human psychology, political economy, business and economics, plant biology, environmental sciences, and health science.

One medium sized comprehensive university has completely revised its curriculum in conjunction with a change in the credit-hour delivery system. Other delivery changes include a rapid expansion of continuing education; offering first year studies by distance education at five rural sites; and providing distance delivery of nursing education. One university has created new undergraduate and graduate programs-business studies, plant biology, environmental science, and health science-which cut across traditional departmental lines. Two others have developed a core curriculum in the humanities. Collaborative arrangements between neighboring universities have been developed to support joint programs, and cooperative programs in partnership with public and private corporations also are increasing.

There were a few mentions of curriculum reduction. A large comprehensive university has closed several departments and cut back their programs. In another, two degree programs were reported to have been eliminated entirely.

\section{Student Body}

Most comments dealt with the significant increases in student numbers at both undergraduate and graduate levels which are being experienced in all types of university and in all provinces. Increases in the order of $25 \%$ to $100 \%$ in undergraduate enrollment were reported. One university referred specifically to increases in the number of mature students. In some cases, these increases have resulted in spite of attempts to limit enrollment, such as by raising admission standards and capping programs and courses. 


\section{Managerial Structure}

Several respondents mentioned extensive turnover of upper management which has resulted in new philosophies and administrative practices. Three universities reported having new presidents, but the most common change involved the office of vice-president. In several cases, new vice-presidential or associate vice-presidential positions have been created, most often bringing a clearer focus on planning and development, especially fund-raising.

One respondent referred to the creation of four new deanships, and another to the creation of four new academic schools. At a large comprehensive university, major changes have occurred in the governance structure: the compositions of the board, Senate, and the committee that allocates funds have been altered "to give all parts of the university more input into decisions and to ensure that the decisions are as open as possible and are just." Only one university hinted at reduction of senior management.

\section{Decision Making Processes}

Reform in decision making is closely tied to strategic planning, the ultimate goal being the enhancement of rationality. The procedural changes result in more democratic participation, especially involving deans. At the same time, new union contracts now require procedural reviews before actions can be taken on faculty matters. One university reported the establishment of a planning and priorities committee, a budget enhancement committee, and a system of unit reviews. Another reported the creation of a president's committee to "provide plans for cuts, redistribution in academic programs and administrative services." A small liberal arts university reported the establishment of an academic policy development committee to "deal with long-range planning and to interface with a more open strategic planning process on campus." In a small specialized university, a procedural change has moved decision making power from a small executive committee to the full board.

A respondent in Nova Scotia reported that the province is attempting to conserve resources by implementing a rationalization review of the entire system. This requires internal decision making regarding the continuance of departments and programs or their amalgamation with other institutions in the province. It is forcing many difficult decisions.

\section{Change Agents}

The perceived and preferred degrees of influence of agents of change at Canadian universities, on a 5-point scale from low to high, are shown in Table 2. 
Table 2

Perceived and Preferred Influence of Agents of Change

\begin{tabular}{lcc}
\hline Agent of Change & $\begin{array}{c}\text { Mean Perceived } \\
\text { Influence }\end{array}$ & $\begin{array}{c}\text { Mean Preferred } \\
\text { Influence }\end{array}$ \\
\hline University board/administration & 3.9 & 4.4 \\
Provincial government/agency & 3.7 & 3.1 \\
Academic faculty or their agents & 3.4 & 4.7 \\
Students or their agents & 2.4 & 4.0 \\
Federal government/agency & 2.2 & 2.4 \\
The public at large & 2.0 & 3.2 \\
\hline
\end{tabular}

The university board and administration are perceived as being most influential, followed by the provincial ministries. Academic faculty are rated third in influence. Students and the general public are seen as having relatively little influence on reform. However, academic faculty are the group of preferred greatest influence, followed by the board and administration, and by students. This suggests a desire for a major redistribution of influence away from provincial governments, giving faculty and students more say in reform.

Methods used to implement reforms are commensurate with the sources of influence. Direct managerial action was viewed as the most significant method of initiating change, followed by financial levers, and system master-planning. The introduction of new legislation or system regulations is the least used method of implementing change in Canadian universities.

\section{Goals of Reform}

Respondents were asked to rate the "apparent" and "preferred" importance of 17 potential goals of reform. The means on a 5-point scale for the top 10 apparent goals and the top ten preferred goals are shown in Table 3. The same goals appear in both lists, and there is a clear similarity in the rank orders. These data reveal that vice-presidents and deans generally support the directions that reform is taking. At the same time, the higher ratings for preferred importance indicate a desire for a clearer goal focus, especially concerning individual potential, general education, social problem solving, effective delivery of education, and equity.

The ratings of goal achievement through recent reforms are relatively low, only two out of 17 cases exceeding the mid-point (3.0) of the achievement scale. These are i) to improve the development of individual potential (3.3); and 
Table 3

Ratings of Apparent and Preferred Goals of Reform

\begin{tabular}{lcc}
\hline Goals of Reform & $\begin{array}{c}\text { Mean Apparent } \\
\text { Importance }\end{array}$ & $\begin{array}{c}\text { Mean Preferred } \\
\text { Importance }\end{array}$ \\
\hline
\end{tabular}

To improve the development

of individual potential

To provide a more solid

foundation of general education

To enhance the prestige and status of the institution

To better prepare citizens to cope with the problems of society

To provide more effective delivery of education

To provide more efficient delivery of education

To expand access to educational opportunities

To provide a more comprehensive curriculum for education and training

To enhance educational services to a local community or region

To provide greater equity in education

* Difference between "apparent" and "perceived" significant at $\mathrm{p} \leq .05$

ii) to provide more efficient delivery of education (3.1). There has been little progress on the other priority goals of reform.

Respondents were asked to describe one major change that they would like to see at their institutions. Enhancing liberal education is a significant priority, and reforms to achieve this include improved teaching and more efficient use of resources. There is a perceived need for greater fairness through equity provisions in staffing and more open student access. Strategic planning is seen to be the touchstone to these desired goals of enhanced effectiveness, efficiency, and equity. But all of these reforms are contingent upon increased levels of public funding. There was a notable absence of desire for radical reform - all were on-going to some extent within the nation's institutions. 


\section{Discussion}

Is there evidence that reform in Canadian universities resembles that in other systems, or are there unique features which set it apart? Given the answer to this question, what insights can be offered to system and institutional leaders interested in bringing about meaningful and lasting change in our universities?

\section{Distinctiveness in Reform in Canadian Universities}

In examining the nature of change in higher education in Europe, van Vught (1989) noted the following characteristics: i) the inherently low innovation resistance of universities; ii) the mainly incremental nature of innovation; iii) responsiveness to external incentives, especially profitability; and iv) the need for congruence of innovations with existing values and practices (pp. 97-102). Likewise, Burton Clark (in Cerych \& Sabatier, 1986) considered the particular nature of reform in the United States and posited that its characteristics were greatly influenced by the extremely decentralized federal structure. Reform is more likely to be generated at lower levels than at higher levels; and, it occurs incrementally by zigs and zags and contradictions; it has small expectations, successes, and failures; it is piecemeal rather than holistic; it depends considerably on institutional leaders; it is market-driven and market-responsive; and, it occurs as unplanned change (p. 260). This is in contrast to centralized political systems where change is more likely to be imposed by government policy and directed from top down, for example in China (Yang, 1987).

Canadian universities resemble their American counterparts in the high incidence of innovation (see, for example, Heiss, 1973). Clark's description of change in the United States matches the Canadian experience, and this is not surprising given the similarities in postsecondary structures (Skolnik \& Jones, 1992). The present survey substantiates the institutional as opposed to systemwide scope of reform, and its piecemeal and modest nature. However, the emphasis on strategic planning suggests that it would be unfair to characterize reform in Canadian universities as unplanned change. Nevertheless, a major incentive for reform appears to be external pressures, and this raises doubts about whether the innovations listed are policy driven reforms or merely contingency responses to the operant social, financial, and political environment .

That levels of funding and profitability are an important stimulus to change in Canadian universities, as in Europe and the United States, should come as no surprise since, according to Stager (1992, p. 134), "financial constraint has dominated universities for almost two decades...Underfunding is the unifying theme in the various problems confronting Canadian universities." Williams 
(1992), from his analysis of new funding mechanisms in the United Kingdom, also stressed the importance of financial instruments of reform: "one of the political discoveries of the 1980's was that higher education institutions, like other economic enterprises, respond to financial incentives" (p. 66).

\section{Implications for Leaders}

While it is acknowledged that financial concerns dominate the world of higher education, the manner of coping presents some choices. Levine (1992) described three basic strategies: raising money, politically easy cuts, and targeted cutting and institutional shaping. Ell (1988) found that involving faculty in measures to develop institutional strategies for cutback management was rated favourably by faculty, and there is evidence of this occurring in Canadian universities through redesigned decision making structures. The data also suggest that Levine's methods are currently in use, especially institutional shaping. This being so, his caution should be carefully weighed - "the result on too many of the campuses attempting this more rational approach has been the unleashing of a political firestorm, with faculty at the center. Over the past year we have witnessed an exodus of college presidents who tried to move in this direction" (p. 4).

Canadian universities appear to be following two of the seven patterns of change described by Murgatroyd (1992, pp.179-182) - those which he calls "almost there" and "fail-safe." The "almost there" pattern may be modest or demanding, but the university just fails to reach its goals over time--"whilst improvement has occurred, it is not at the anticipated level" (p.179). The "failsafe" pattern is well within the university's capabilities and is "designed to stay within the comfort zone of challenge and is not intended to include the possibility of risk or failure" (p.179). If this is a fair assessment of the situation in Canadian universities, then leaders in these institutions might wish to consider bolder strategies of reform which would lead to more lasting and significant change which Murgatroyd describes as "sustainable steep-slope improvement" whereby the university is "outstanding in its ability to surpass its goals and achieve beyond that which it thought possible" (p.181). This is only likely to happen if postsecondary institutions, provincial governments, and public and business organizations across the nation can join together in a spirit of partnership and recognition of the others' needs.

This ideal may be attainable in the entrepreneurial and adaptive university (EAU) which sees a joining of the traditional values of autonomy and client service. As Davis (1987) describes it: 
...the concept of EAU is based on open systems theory, and the necessity of maintaining a state of creative equilibrium with the environment. It involves, especially in turbulent times, a careful scanning of environmental stimuli of a political, social and economic nature, and adjusting the activities, operations and mission of the university to keep pace with advancements. In this way, the organization keeps its external (political, social and industrial) reference groups happy and committed, and maintains itself in a sound and healthy condition. It is proactive, opportunistic, has a predictive capability, and has a strong service orientation encapsulated in a definitive university mission. (p. 15)

\section{Conclusion}

The two questions posed in the introduction are returned to by way of conclusion-are Canadian universities as unresponsive as government officials believe? Or is there evidence that universities are adapting to changing expectations? The answer to both could be "yes." There is clear evidence that universities are in a ferment of change, and while most innovations seem to be incremental fail-safe changes, many universities appear to be preparing themselves for more significant reform by restructuring their decision making systems and through new institutional planning processes. Several instances of changes in institutional mandates and goals were reported. Why then is the answer to the first question also yes? Perhaps because the changes reported to date may not reflect the sustained commitment to reform that governments believe is necessary and are demanding. The "not quite there" may be not quite good enough.

\section{References}

Cerych, L., \& Sabatier, P. (1986). Great expectations and mixed performance: The implementation of higher education reforms in Europe. Stoke-on-Trent: Trentham Books Ltd.

Davis, J.L. (1987). The entrepreneurial and adaptive university. International Journal of Institutional Management in Higher Education, 11(1), 12-104.

Dennison, J.D., \& Levin, J.S. (1988). Canada's community colleges in the nineteen eighties: Responsiveness and renewal. Toronto: The Association of Canadian Community Colleges.

Ell, J. (1988). Faculty perceptions of financial constraint in universities. Unpublished doctoral dissertation, Edmonton: University of Alberta. 
Heiss, A. (1973). An inventory of academic innovation and reform. Berkeley: Carnegie Commission on Higher Education.

Hodgkinson, H. (1971). Institutions in transition: A profile of change in higher education. New York: McGraw-Hill.

Levine, A. (1992). Why colleges are continuing to lose the public trust. Change, July/August.

Mathurin, C. (1991). Research Report \#4: Enquête sur les innovations récentes en matière d'enseignement dans les universités canadiennes. Ottawa: Commission of Inquiry on Canadian University Education.

Meek, V., Goedegebuure, L., Kivinen, O., \& Rinne, R. (1991). Policy change in higher education: Intended and unintended outcomes. Higher Education, 21(4), 451-459.

Millard, R. (1991). Today's myths and tomorrow's realities. San Francisco: Jossey-Bass.

Miller, R. (1990). Major American higher issues and challenges in the 1990's. London: Jessica Kingsley.

Murgatroyd, S. (1992). A new frame of reference for managing schools: TQM. School Organization, 12(2).

Public Affairs Management Inc. (1991). Research Report \#5: Survey of perceptions of universities among provincial government officials. Ottawa: Commission of Inquiry on Canadian University Education.

Ronayne, J. (1988). An abridgment of higher education: A policy statement. University of New South Wales.

Sheffield, E. (1978). Systems of higher education in Canada: The national scene. New York: International Council for Educational Development.

Silver, H. (1990). A higher education. London: The Falmer Press.

Skolnik, M., \& Jones, G. (1992). A comparative analysis of arrangements for state coordination of higher education in Canada and the United States. Journal of Higher Education, 63(2), 121-142.

Small, J., Konrad, A., Hassen, M., \& Pickard, B. (1976). Renewal in post-secondary institutions: An analysis of strategies. Edmonton: Department of Educational Administration, University of Alberta.

Stager, D. (1992). Financing universities in Canada. Higher Education in Europe, 17(1).

Stadtman, V. (1980). Academic adaptations: Higher education prepares for the $1980 \mathrm{~s}$ and 1990s. San Francisco: Jossey-Bass.

van Vught, F., ed (1989). Governmental strategies and innovation in higher education. London: Jessica Kingsley.

Williams, G. (1992). An evaluation of new funding mechanisms in British higher education: Some micro-economic and institutional management issues. Higher Education in Europe, 17(1).

Yang, P. (1987). Several questions concerning reform of the college management system. Chinese Education, 19(4), 42-45. 